Canadian University Music Review

Revue de musique des universités canadiennes

\title{
Hambraeus: Intrada: "Calls." Tornado. Tides. McGill University Records 76001
}

\section{John Ditsky}

Numéro 3, 1982

URI : https://id.erudit.org/iderudit/1013840ar

DOI : https://doi.org/10.7202/1013840ar

Aller au sommaire du numéro

Éditeur(s)

Canadian University Music Society / Société de musique des universités

canadiennes

\section{ISSN}

0710-0353 (imprimé)

2291-2436 (numérique)

Découvrir la revue

Citer ce compte rendu

Ditsky, J. (1982). Compte rendu de [Hambraeus: Intrada: "Calls." Tornado. Tides. McGill University Records 76001]. Canadian University Music Review / Revue de musique des universités canadiennes, (3), 227-227.

https://doi.org/10.7202/1013840ar

All Rights Reserved @ Canadian University Music Society / Société de musique des universités canadiennes, 1982
Ce document est protégé par la loi sur le droit d'auteur. L'utilisation des services d'Érudit (y compris la reproduction) est assujettie à sa politique d'utilisation que vous pouvez consulter en ligne.

https://apropos.erudit.org/fr/usagers/politique-dutilisation/ 
BACH: Sonatas for Viola da Gamba and Harpsichord, BWV 1027-9. Mary Cyr, gamba; John Grew, harpsichord. MCGILL UNIVERSITY RECORDS, 78007, produced by Donald Steven.

The only thing I don't like about this release is the paper inner sleeve. After an untitillating experience with the last "academic" performance of these works sent me for review, I lowered the stylus to this Canadian vinyl with no great haste, and so I was really pleased to find myself quickly enveloped by the great warmth of these sensitive interpretations. The artists are both professors at McGill University in Montreal, which seems to have acquired fine recording facilities for its Pollack Concert Hall. This is pellucid and poised Bach playing by two extremely well-matched interpreters and instruments. The lower register of the harpsichord blends exceptionally well with the gamba.

The warmth (to repeat the noun) of this disc derives from an abiding sense of a surrender to the scores facilitated rather than impeded by thorough scholarship. Though I'll look to Rose/Gould or Cervera/ Puyana for these works in my more manic moods, this is the version to which I'll return, often I'm sure, for a glimpse of the simultaneously transcendental and thoroughly human serenity of Bach.

Edward Strickland (FANFARE, V/4 (1982), 86]

HAMBRAEUS: Intrada: "Calls." Tornado. Tides. MCGILL UNIVERSITY RECORDS 76001.

Though the vogue for this sort of thing may well have passed, these three "concrète and synthesizer" pieces by a Swedish composer now resident in Canada are particularly effective, thanks partially to what might be termed their programmatic coherence. Echoes of Swedish pasture cow-calls, of winds, and of waves are obvious enough in Hambraeus's re-workings, but are nonetheless enjoyable in spite of their patent verisimilitude. One can only hurriedly note that anyone interested in this sort of music should own these examples. The recording is fine, the pressing adequate, but the junky inner sleeve can have its way with your disc before you even spring it from its plastic cell.

John Ditsky

[FANFARE, V/4 (1982), 158]

PATRIQUIN: Hangman's Reel-Ballet (With Music for Fiddle and Piano). Jean Carignan, fiddle; Gilles Losier, piano; Orchestra of Les Grands Ballets Canadiens conducted by Vladimir Jelinek. McGILL UNIVERSITY RECORDS 80010), produced by Donald Steven. 